Research article

\title{
THERMAL VISION EXAMINATION OF VASOCONSTRICTION AND VASODILATATION OF BLOOD VESSELS UNDER THE INFLUENCE OF LOCAL ANESTHETIC SOLUTIONS
}

\author{
ĐUKIĆ Igor ${ }^{1}$, SELAKOVIĆ Srećko ${ }^{2}$, BUBALO Marija ${ }^{3 *}$, SELAKOVIĆ Jovana ${ }^{4}$, \\ TATIĆ Zoran ${ }^{3}$
}

\begin{abstract}
${ }^{1}$ University of Banjaluka, Faculty of Medicine, Study programe Stomatology, Department of Oral surgery; ${ }^{2}$ Dental Clinic of Vojvodina Novi Sad, Department of Oral Surgery, Faculty of Medicine, University of Novi Sad; ${ }^{3}$ Clinic for Dentistry Military Medical Academy, Department for Implantology, Belgrade, Serbia; ${ }^{4}$ Dental Clinic of Vojvodina Novi Sad, Department of Dentistry, Faculty of Medicine, University of Novi Sad; 2. Specialist Dental Practice "Oluški - Ilić" Novi Sad
\end{abstract}

(Received 11 April, Accepted 28 August 2018)

\begin{abstract}
A quality local anesthesia is one of the imperatives of performing dental interventions, and especially oral-surgical interventions, where the success of the oral-surgical intervention is seen through the success of local anesthesia. There is a high number of different local anesthetic solutions (LAS) on the market, holding different levels of vasoconstrictors which are attributed with causing numerous complications during the local anesthesia. The aim of this research is to point out the temperature changes caused by different LAS, depending on the strength and the concentration of LAS, using thermal vision camera. Testing was performed on 70 experimental Wistar rats, aged 4.5 months, with an average weight of 250 grams, male, and divided into seven groups of 10 animals each, depending on the applied anesthetic. After injecting the anesthetic solution into the haunch area, a stopwatch was turned on and control measurements were conducted for a period of two hours. All footage from the thermal camera was later transferred to a computer unit. Occurrence of multiple temperatures in the rats' examined regions, compared to the control region, was noticed only when applying $2 \%$ pure lidocaine (without vasoconstrictors). The highest temperature drop, compared to the control region, was noticed with $2 \%$ mepivacaine with adrenaline $(1: 100000)$, and $2 \%$ mepivacaine with noradrenaline $(1: 100000)$, five minutes after applying the local anesthetic. In conclusion: vasoconstricting effects are most expressed in the fifth minute after applying LAS, and there are minimal differences between the effects of adrenaline and noradrenaline, in the examined combinations together with LAS.
\end{abstract}

Key words: LAS, adrenaline, noradrenaline, thermal camera, temperature

\footnotetext{
*Corresponding author: e-mail: bubalo.marija@yahoo.com
} 


\section{INTRODUCTION}

Pain is one of the main somatic senses, and it represents a negative sensual and emotional experience, which always appears when there is a negative action on the organism, causing tissue damage, to which an individual reacts in a manner to try and remove that painful stimulus [1].

Anesthesia is a procedure which eliminates pain during medical interventions. Local anesthetic solutions (LAS) are used with the goal of eliminating pain when performing dental interventions, and, over time, they have evolved into very useful and powerful means of eliminating pain. A quality local anesthesia is one of the imperatives of performing dental interventions, and especially oral-surgical interventions, where the success or oral-surgical intervention is seen through the success of local anesthesia. LAS are used for over 120 years [2,3]. There is a high number of different local anesthetic solutions on the market, holding different levels of vasoconstrictors which are attributed with causing numerous complications during local anesthesia. Out of the vasoconstrictors added to LAS, adrenaline (epinephrine) is most often used, and rarely noradrenaline (norepinephrine). Vasoconstrictors are substances which, after infiltrating local tissue, cause the constriction of blood vessels, and therefore lower blood flow through tightened blood vessels, which causes a limited local tissue ischemia. At the location of local tissue ischemia, consequentially, a lowering of local tissue temperature occurs, the intensity of which varies on the type of the vasoconstrictor, its amount and concentration, and the LAS type with which the vasoconstrictor is combined $[4,5]$.

This change in the temperature of a limited body area is possible to measure very accurately, but it can also be shown using thermal vision cameras. Thermal vision cameras are devices which allow conducting of thermal surround visualization. All objects in the surroundings emit infrared (IR) radiation as a function of their temperature. The higher the temperature of some object, the more IR radiation it emits, and vice versa. With the help of thermal vision cameras, a non-contact temperature measuring of an object is performed, by a camera recording the IR radiation emission, which it then converts into an image we address as thermogram, and the amount of recorded IR radiation emission is shown as temperature shown in degrees Celsius $\left({ }^{\circ} \mathrm{C}\right)$ or degrees Kelvin $\left({ }^{\circ} \mathrm{K}\right)$. Infrared thermography as such represents the creation of an image, photograph or a video recording, from the pattern of IR light invisible to a human eye [6].

Such a manner of examining LAS potential with different concentrations of vasoconstrictors, as well as such a manner of testing, has not yet been performed. This research is to point out temperature changes caused by different LAS, depending on the LAS strength and concentration. It's also to point out that different LAS types, with different concentrations, may produce equally satisfying analgetical effects, and that in such a way an answer can be given to a question of LAS choice- depending on the patient's medical condition. It's also to point out the technological advance in the 
field of thermal vision, and to show the possibility of applying modern thermal vision equipment and IR thermography in modern dental practice and in scientific-research within dentistry.

The goals of the research were to examine, in certain time intervals, the temperature differences on the skin of experimental animals, which occur under the effect of tested LAS, to determine whether temperature differences on the skin of the experimental animal were statistically significant in relation to the origin time, to determine whether there are statistically significant differences between tested combinations of local anesthetics and vasoconstrictors in the same control intervals, as well as to point out the significance and possibilities of using thermal vision as a scientific and diagnostic method in dentistry.

The pioneer of testing the effects of local anesthetics with the thermovision method is Lindorf. In our study, we enlarged the selection of local anesthetics, and examined the effects of a more recent thermoset methodology. [7-9]

\section{MATERIAL AND METHODS}

Testing was performed on 70 experimental Wistar rats, aged 4.5 months, with an average weight of 250 grams, male, and divided into seven groups of 10 animalsdepending on the applied anesthetic.

- First group - 2\% lidocaine (without vasoconstrictors)

- Second group - 2\% lidocaine, with adrenaline 1:80 000

- Third group - 2\% lidocaine, with adrenaline 1:200 000

- Fourth group - 4\% articaine, with adrenaline 1:200 000

- Fifth group - 2\% mepivacaine, with adrenaline 1:100 000

- Sixth group - 2\% mepivacaine, with noradrenaline 1:100 000

- Seventh group - 3\% mepivacaine (without vasoconstrictors)

Upon inducing the animals into general anesthesia (Ketamine $10 \mathrm{mg} / \mathrm{ml}$ and Xylazine $20 \mathrm{mg} / \mathrm{ml}$ ), preparation of recording area was performed, and that was both haunch areas of the experimental animals. The areas were shaved using a razor, and the area of the application of the local anesthetic and the recording area were labeled using a black marker, in the shape of a circle. All temperatures of rats' haunch areas were registered using a thermal vision camera Guide infrared, model MoBIR M8.

After positioning the experimental animal on a stand, precise positioning of the working stand with the experimental animal into a suitable position below the thermal camera was performed. The thermal camera was placed and secured on an immovable stand, fixed and secured in a suitable position. The distance between the thermal camera lens and the object of the recording was a constant $30 \mathrm{~cm}$, and under an angle of $90^{\circ}$; they were constant due to the effect of distance and angle on the recording 
accuracy. The used tripod and stand was Velbon DF 40, the recording area on the right thigh muscle was labeled by a black thin circle and it was additionally secured and positioned using a laser pointer integrated into the camera.

A digital stopwatch was used to accurately and precisely determine the interval of the recording, which was performed at the following times:

- T0 - temperature of the thigh region before LAS application, and 15 minutes after putting the animal into general anesthesia,

- T5 -temperature of the thigh region, 5 minutes after LAS application,

- T15 -temperature of the thigh region, 15 minutes after LAS application,

- T30 -temperature of the thigh region, 30 minutes after LAS application,

- T60 -temperature of the thigh region, 60 minutes after LAS application,

- T90 -temperature of the thigh region, 90 minutes after LAS application,

- T120 -temperature of the thigh region, 120 minutes after LAS application.

The local anesthetic was injected into the rats' thigh muscle. 40-units insulin syringes were used. All tested LAS were given in the amount of $20 \mathrm{mg}$ per kilogram of body weight, or $0.1 \mathrm{ml}$ per 100 grams of body weight. After the injection, the stopwatch was turned on, and control measurements were performed during the period of two hours. All received values were written down into appropriate protocols.

All recordings were automatically saved into the thermal vision camera's memory, and were also listed under an appropriate code or serial number of the recording. That code was written down into the protocols. After performed recording, experimental animals were returned to their cages, to a post-anesthesia recovery. All recordings from thermal vision camera were later on transferred to a computer unit, which possessed a registered software for thermogram processing installed. Labeling of recording position and extrapolation of the recording data was performed within the software (Fig. 1 and 2).

The whole procedure was repeated for each tested LAS, under the same conditions and in the same manner, by which we attempted to exclude as many factors which could affect quality and results of the thermography.

Each group received one LAS, and all values received during the testing were noted down in the appropriate protocols. The first group, which received $2 \%$ lidocaine without vasoconstrictors, i.e. anesthetic only, is the control group for all other LAS which contain one of the vasoconstrictors in a certain amount (concentration and dose). The first group also serves to compare the values obtained by Helmut $\mathrm{H}$. Lindorf in his research.

This research used indicators of descriptive statistics (arithmetic mean, arithmetic mean standard error, extreme values, quartiles, median and trust interval for arithmetic mean). 
Student's t-test for paired samples was used for comparing mean values of temperature differences in different time intervals after applying one of the local anesthetics.

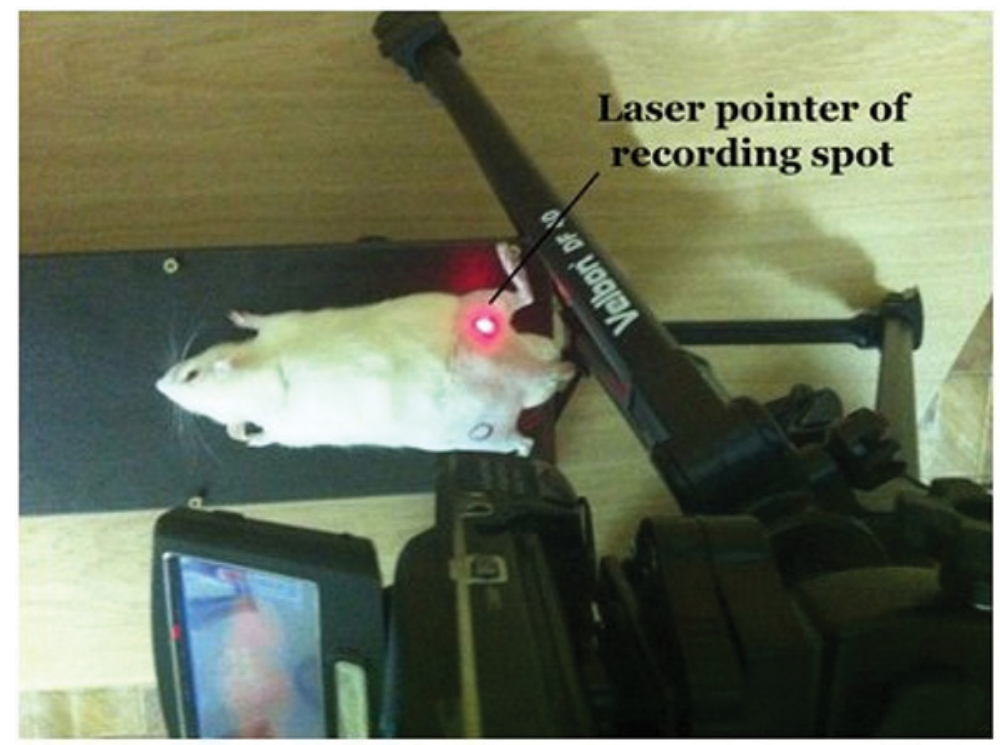

Figure 1. Fixing the position using the laser pointer

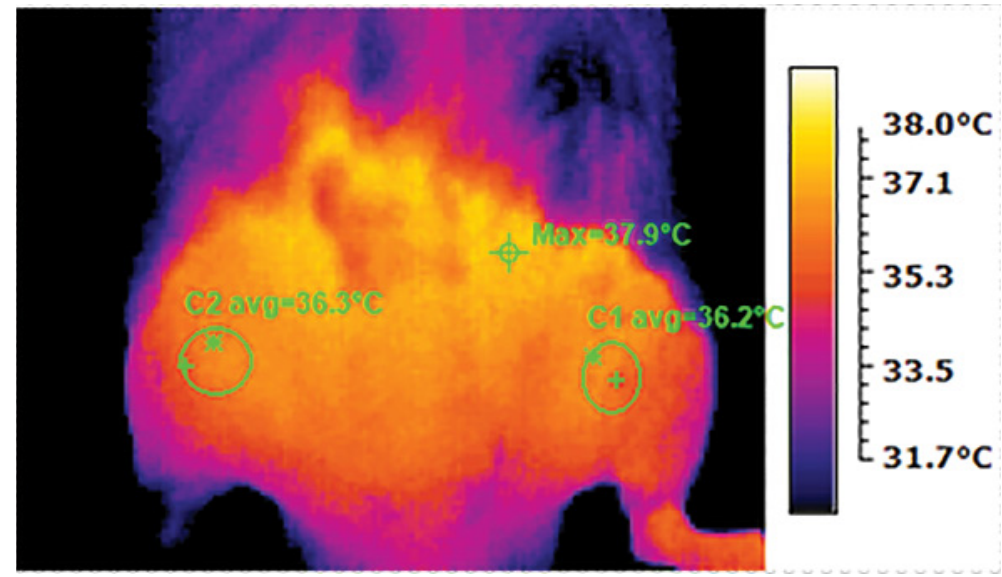

Figure 2. Thermogram of rat's thigh region

Student's t-test for independent samples was used for comparing mean values of temperature differences in the same time intervals after applying different local 
anesthetics (if the difference of observed characteristics variants was not statistically significant) and non-parameter Mann-Whitney test.

\section{RESULTS}

Comparative differences in temperatures between rats' tested regions and control regions, for all the anesthetics, at different time intervals, are shown in Graph 1.

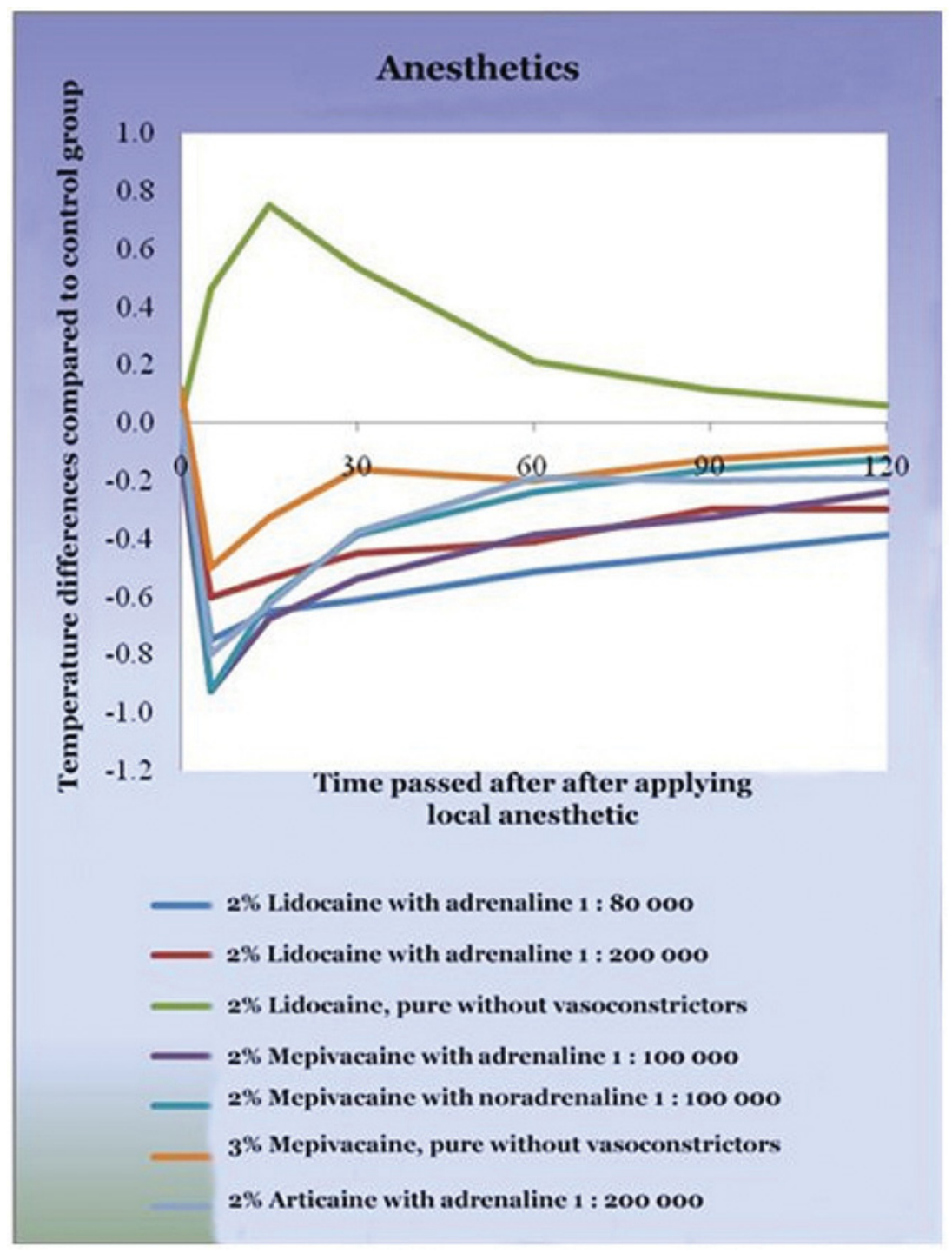

Graph 1. Comparative differences in temperatures for all anesthetics 
The appearance of multiple temperatures in the examined rats' region, compared to the control region, was noticed only when applying $2 \%$ pure lidocaine (without vasoconstrictors).

The largest temperature drop, compared to the control region, five minutes after applying the local anesthetic, was noticed with $2 \%$ mepivacaine with adrenaline $(1: 100$ $000)$ and $2 \%$ mepivacaine with noradrenaline $(1: 100000)$, while, compared to other anesthetics, $2 \%$ lidocaine with adrenaline $(1: 80$ 000) gives the largest temperature drop 30, 60, 90 and 120 minutes after applying (Table 1).

Table 1. Comparing 2\% lidocaine with adrenaline $1: 80000$ with other anesthetics

\begin{tabular}{|c|c|c|c|c|c|c|c|c|}
\hline \multicolumn{2}{|l|}{$\begin{array}{l}2 \% \text { Lidocaine } \\
\text { with adrenaline } \\
1: 80000 \\
\text { compared to } \\
\text { other anesthetics }\end{array}$} & $\begin{array}{c}\text { T0 } \\
\text { difference }\end{array}$ & $\begin{array}{c}\text { T5 } \\
\text { difference }\end{array}$ & $\begin{array}{c}\mathrm{T} 15 \\
\text { difference }\end{array}$ & $\begin{array}{c}\text { T30 } \\
\text { difference }\end{array}$ & $\begin{array}{c}\text { T60 } \\
\text { difference }\end{array}$ & $\begin{array}{c}\text { T90 } \\
\text { difference }\end{array}$ & $\begin{array}{c}\text { T120 } \\
\text { difference }\end{array}$ \\
\hline \multirow{3}{*}{$\begin{array}{l}2 \% \text { Lidocaine } \\
\text { with adrenaline } \\
1: 200000\end{array}$} & $\mathrm{t}$ & 0.287 & 2.510 & 3.000 & 3.153 & 1.776 & 2.291 & 1.263 \\
\hline & df & 9 & 14 & 14 & 12 & 14 & 14 & 14 \\
\hline & $\mathrm{p}$ & 0.780 & 0.025 & 0.010 & 0.009 & 0.097 & 0.038 & 0.227 \\
\hline \multirow{3}{*}{$\begin{array}{l}\text { 2\% Lidocaine, } \\
\text { pure without } \\
\text { vasoconstrictors }\end{array}$} & $\mathrm{t}$ & -0.805 & -15.590 & -17.967 & -16.050 & -14.631 & -8.801 & -9.431 \\
\hline & $\mathrm{df}$ & 18 & 14 & 14 & 14 & 14 & 14 & 14 \\
\hline & $\mathrm{p}$ & 0.431 & $<0.001$ & $<0.001$ & $<0.001$ & $<0.001$ & $<0.001$ & $<0.001$ \\
\hline \multirow{3}{*}{$\begin{array}{l}2 \% \text { Mepivacaine } \\
\text { with adrenaline } \\
1: 100000\end{array}$} & $\mathrm{t}$ & 2.377 & 2.824 & 0.552 & -1.461 & -2.523 & -2.118 & -2.923 \\
\hline & df & 18 & 14 & 14 & 11 & 14 & 14 & 14 \\
\hline & $\mathrm{p}$ & 0.029 & 0.014 & 0.590 & 0.171 & 0.024 & 0.053 & 0.011 \\
\hline \multirow{3}{*}{$\begin{array}{l}2 \% \text { Mepivacaine } \\
\text { with } \\
\text { noradrenaline } \\
1: 100000\end{array}$} & $\mathrm{t}$ & -0.828 & 1.698 & -0.646 & -3.610 & -5.763 & -5.089 & -5.584 \\
\hline & $\mathrm{df}$ & 18 & 14 & 14 & 14 & 14 & 14 & 14 \\
\hline & $\mathrm{p}$ & 0.418 & 0.112 & 0.529 & 0.003 & $<0.001$ & $<0.001$ & $<0.001$ \\
\hline \multirow{3}{*}{$\begin{array}{l}3 \% \text { Mepivacaine, } \\
\text { pure without } \\
\text { vasoconstrictors }\end{array}$} & $\mathrm{t}$ & -1.375 & -2.820 & -4.816 & -7.060 & -5.383 & -4.816 & -5.657 \\
\hline & df & 18 & 14 & 14 & 14 & 14 & 14 & 14 \\
\hline & $\mathrm{p}$ & 0.186 & 0.014 & $<0.001$ & $<0.001$ & $<0.001$ & $<0.001$ & $<0.001$ \\
\hline \multirow{3}{*}{$\begin{array}{l}2 \% \text { Articaine } \\
\text { with adrenaline } \\
1: 200000\end{array}$} & $\mathrm{t}$ & -0.459 & 0.798 & -0.333 & -4.146 & -6.559 & -4.410 & -3.209 \\
\hline & df & 18 & 14 & 9 & 14 & 14 & 14 & 14 \\
\hline & $\mathrm{p}$ & 0.652 & 0.438 & 0.747 & 0.001 & $<0.001$ & 0.001 & 0.006 \\
\hline
\end{tabular}

t - Value of Student's t-test; df - Degrees of Freedom; p - Statistical significance

\section{DISCUSSION}

Medical thermography is a very useful measurement method, which can, with a high level of reliability, be used for diagnostic, but also research purposes. Medical 
thermography is used, in its primitive form, since ancient times, from Hippocrates who spread a thin layer of mud on his patients, and then monitored the speed of mud drying and its color change. Mud dried faster and changed its color on those parts of the body where the local temperature was elevated, which was a sign of a local disorder or ailment. This is an example of primitive thermography which was used with great success [10].

Nowadays, it can also be used to assess the condition of the periodontium, monitor the course of parodontological ailments, in oral surgery to measure thermic effects of rotating socketed machine devices on the bone and surrounding tissue, to measure the inflammation zone with determining the area of highest and lowest temperature as well as the area of necrotic processes, and also to monitor the success of certain surgergical procedures [11].

Thermography can be also used in the field of sport, sport medicine ans sport rehabilitation [12].

Noticeable use is also in monitoring the ailment of the temporomandibular joint. In a study conducted by Gratt BM, Sickles EA the capability of electronic thermography to identify inner disorders of temporomandibular joint is assessed. Study was conducted on 30 patients with inner temporomandibular joint disorders, which was checked using orthopantomography. Electronic thermography was conducted using Arema 870 thermographic unit. Results show a low level of thermal symmetry in patients with inner disorder on temporomandibular joint, absolute measurement temperature and measurement of the temperature in the zone of affected temporomandibular joint show significant value differences $\left(0.4^{\circ} \mathrm{C}\right.$ up to $\left.0.8^{\circ} \mathrm{C}\right)[13,14]$.

Application of thermovision is also possible in anaesthesiology and general surgery. The paper examined the change of temperature in the distal parts of the foot after the application of an anesthetic block for $\mathrm{n}$. schiaticus with local anesthetic solution with ropivacaine [15].

LAS effect on peripheral circulation is described and explained in detail by Lindorf - using a thermal vision camera. In his research, he used exclusively pure LAS forms, without adding vasoconstrictor substances. He examined the following anesthetics: $2 \%$ procaine, $3 \%$ butanilicaine, $2 \%$ lidocaine, $4 \%$ prilocaine and 3\% mepivacaine According to the results of his research, all listed anesthetics, except $3 \%$ mepivacaine, are vasodilatators. $3 \%$ mepivacaine is, by results of his research, a mild vasoconstrictor. The most expressed vasodilatation was caused by $2 \%$ procaine. It led to increase in local temperature by $2.1^{\circ} \mathrm{C}$, and that was the maximum increase in temperature which he labeled with $100 \%$ [16].

By its influence on peripheral circulation, 2\% lidocaine is a vasodilatator, which was shown by the results of this research. When applying $2 \%$ lidocaine (without vasoconstrictors), an increase in the temperature on the area of the applied LAS was noted, compared to the control area. The highest temperature increase, compared to rats' control area, was noted 15 minutes after applying the mentioned anesthetic. 
Average temperature increase in 15 minutes is $0.75^{\circ} \mathrm{C}\left(0.61^{\circ} \mathrm{C}-0.89^{\circ} \mathrm{C}\right)$. After 15 minutes, the temperature increase lowers with the time passed, and after 120 minutes, the average temperature increase is $0.06^{\circ} \mathrm{C}\left(0.01^{\circ} \mathrm{C}-0.11^{\circ} \mathrm{C}\right)$.

Due to the addition of adrenaline, which is a vasoconstrictor, this combination of LAS and vasoconstrictor causes vasoconstriction of the peripheral blood vessels, and, consequentially, a temperature drop at the spot where LAS is applied. When applying $2 \%$ lidocaine with adrenaline $(1: 200000)$, the largest temperature drop is five minutes after applying the mentioned anesthetic. Average temperature drop after five minutes is $0.60^{\circ} \mathrm{C}\left(0.54^{\circ} \mathrm{C}-0.66^{\circ} \mathrm{C}\right)$. After five minutes, temperature drop lowers with time passed, and after 120 minutes average temperature drop, compared to control group rats, equals $0.30^{\circ} \mathrm{C}\left(0.19^{\circ} \mathrm{C}-0.41^{\circ} \mathrm{C}\right)[17]$.

By its effect on local circulation, 3\% mepivacaine is a mild vasoconstrictor, it locally produces a decrease in tissue temperature, which was shown by the results of this research, and confirmed by Lindorf's research results.

When applying 3\% pure mepivacaine (without vasoconstrictors), the largest temperature drop in the affected region, compared to control region, was noted five minutes after applying the mentioned anesthetic. Average temperature drop after five minutes is $0.50^{\circ} \mathrm{C}\left(0.36^{\circ} \mathrm{C}-0.64^{\circ} \mathrm{C}\right)$. After five minutes, temperature drop lowers with the time passed, and after 120 minutes temperature drop equals $0.09^{\circ} \mathrm{C}\left(0.02^{\circ} \mathrm{C}\right.$ $\left.-0.16^{\circ} \mathrm{C}\right)[18]$.

Combined with vasoconstrictor substances, the local vasoconstrictor effect is even more expressed. Consequentially, lowering of the local temperature is higher than with pure form of mepivacaine. When applying $2 \%$ mepivacaine with adrenaline (1 : 100 000), the largest temperature drop was noted five minutes upon applying the mentioned anesthetic. Average temperature drop after five minutes is $0.93^{\circ} \mathrm{C}\left(0.85^{\circ} \mathrm{C}\right.$ $\left.-1.00^{\circ} \mathrm{C}\right)$. After five minutes, temperature drop lowers with the time passed, and after 120 minutes average temperature drop equals $0.24^{\circ} \mathrm{C}\left(0.17^{\circ} \mathrm{C}-0.30^{\circ} \mathrm{C}\right)$.

When applying 2\% mepivacaine with noradrenaline (1 : 100 000), the largest temperature drop was noted five minutes after applying the mentioned anesthetic. Average temperature drop after five minutes is $0.93^{\circ} \mathrm{C}\left(0.75^{\circ} \mathrm{C}-1.10^{\circ} \mathrm{C}\right)$. After five minutes, temperature drop lowers with the time passed, and after 120 minutes average temperature drop, compared to control group rats, equals $0.13^{\circ} \mathrm{C}\left(0.08^{\circ} \mathrm{C}-0.17^{\circ} \mathrm{C}\right)$ [19].

Van der Bijl and Hirota state that noradrenaline is a potent stimulator of the $\alpha$ receptors and a very strong vasoconstrictor. There are documented cases of tissue necrosis and tissue surface desquamation at the spot where solution with noradrenaline is applied. For those reasons, noradrenaline cannot be suggested as a vasoconstrictor substance for use in dentistry [20,21].

Henschler and Rummel, describing the effects of adrenaline and noradrenaline on blood pressure, point out significant differences. Namely, adrenaline increases 
systolic blood pressure (1), decreases diastolic (2), while mean blood pressure remains unchanged, and the pulse becomes accelerated (1). Noradrenaline elevates all three blood pressures - systolic, diastolic, mean (1), and pulse slows down [22].

Out of all the stated stances, one can notice a large disagreement between certain authors about the use of the type and the amount of vasoconstrictor substances within the LAS composition. Most of the stances are that noradrenaline should not be used in LAS composition. Reasons are different, for example, that the effect of vasoconstriction is weak compared to adrenaline, and four times less potent, that it causes local necrosis, although used concentration is not mentioned, that it causes rise in blood pressure over $200 \mathrm{mmHg}$, etc. In this research, one LAS was used, which had noradrenaline in its composition. $2 \%$ mepivacaine was used, combined with noradrenaline $1: 100$ 000. Decrease in local temperature which occurred is equivalent to the temperature decrease achieved by applying $2 \%$ lidocaine with adrenaline in the concentration of $1: 80$ 000. It indirectly shows that these two LAS achieve the same local vasoconstrictor effect.

\section{CONCLUSION}

Based on everything stated, one can conclude that temperature changes which occurred are a consequence of the vasoconstrictor and vasodilatator effects of tested LAS and vasoconstrictor substances. Vasoconstrictor effect is mostly expressed in the fifth minute upon LAS being applied, and that there are minimum differences between the effects of adrenaline and noradrenaline in the tested combinations with LAS. That is the case when comparing 2\% lidocaine with adrenaline 1:80000 and 2\% mepivacaine with noradrenaline 1: 100000 in T5 and T15. The conclusion is that these two different LAS with different vasoconstrictors produce the same local effects on the peripheral circulation. That is significant, as it answers the question of justification of the mentioned LAS being used with a certain amount of patients, which is a confirmation of a certain number of research on that subject, but it is also an incentive for further analysis of reasons not to use the mentioned LAS combination 2\% mepivacaine with noradrenaline 1: 100000 .

This method can be used in scientific-research purposes, in all research where it is necessary to accurately measure temperature changes and temperature differences, while visualization of temperature changes is necessary at the same time.

\section{Authors' contributions}

ĐI carried otu the experimental part. SS took the photos with termovision camera. BM did the statistical analysis. SJ participated in study design and coordination and helped to draft the manuscript. TZ approve and supervise the final text fo manuscript. All authors participated in the drafting of the manuscript and have read and approved the final manuscript. 


\section{Declaration of conflicting interests}

The author(s) declared no potential conflicts of interest with respect to the research, authorship, and/or publication of this article.

\section{RFERENCES}

1. Juretić M., Differential diagnosis of orofacial pain, Sveučilište u Rijeci, 2005. (Croatian)

2. Selaković S., Pharmacology of local anesthetics and diabetes mellitus, Naučna stomatološka misao u Vojvodini aktuelna saznanja, Univerzitetska naučna knjiga, Univerzitet u Novom Sadu, 2003; prilog 1; 1-57. (Serbian)

3. Miše I., Oral surgery, Jugoslavenska medicinska naklada, Zagreb, 1983. (Croatian)

4. Euliano T. Y., Gravenstein J. S., Esential anesthesia from science to practice. Cambridge University Press, New York, 2004.

5. Sisk L. A., Vasoconstrictors in Local Anesthesia for Dentistry, American Dental Society of Anesthesiology, Anesth. Prog. 1992; 39(6): 187-193.

6. Vitetta L., Johnson M., Cortizo F., Sali A., Contact-Thermography-response to queries, Graduate School of Integrative Medicine, Swinburne University 2003

7. Lindorf H. H., Investigation of the vascular effect of newer local anesthetics and vasoconstrictors, Universitatskieferklinik, Erlangen, Germany, Oral Surgery, 1979; 48(4): 292-297.

8. I. Đukić. Examing the degree of vasocontriction and vasodilatation of blood vessels under the influence of local anesthetic solutions using thermal vision. master paper work. University of Banjaluka, Medicine faculty, Department of Oral surgery. Banjaluka 2012. (Serbian)

9. I. Đukić. The clinical use of thermovision in testing vasodilatation and vasoconstriction under influence of different local anesthetics, International scientific conference dentistry, Proceedings of the International scientific conference Dentistry Novi Sad: Dental Clinic of Vojvodina, 2017; 1: 181-189.

10. Ring E. F. J., The Historical development of thermal imaging in medicine, Herbeden Histrocal Series, Rheumatology, 2004; 43: 800-802.

11. Sudhakar S., Bina K., Thermography in dentistry-revisited, International Journal of Biological \& Medical Research, 2011; 2(1): 461-465.

12. Vukašin Badža, Vojin Jovančević, Franja Fratrić, Goran Roglić, Nenad Sudarov, Possibilities of thermovision application in sport and sport rehabilitation, Vojnosanit Pregl 2012; 69(10): 904-907. (Serbian)

13. Gratt B.M., Anbar M., Thermology and facial telethermography: Part II, Current and future clinical applications in dentistry, Dento maxillofac Radiol, 1998; 27: 68-74.

14. McBeth S.A., Gratt B.M., A cross-sectional thermographic assessment of TMJ problems in orthodontic patients, Am J Orthod Dentofac Orthop. 1996; 109: 481-488

15. F.G.A.M. van Haren, L. Kadic, J.J. Driessen, Evaluation of the success of sciatic nerve blockade by skin temperature measurement through infrared thermography. Radboud University Medical Centre, PO Box 9101, 6500HB, Nijmegen. Conference Paper · January 2014. DOI: $10.21611 /$ qirt.2014.022. 
16. Lindorf H. H., Investigation of the vascular effect of newer local anesthetics and vasoconstrictors, Universitatskieferklinik, Erlangen, Germany, Oral Surgery, 1979; 48(4): 292-297.

17. Lejla A., Lidokain 2\% injekcije, Lidokain klorid, Lokalni anestetik N01BB02, 2010.

18. Pinchin, Mepivacain Hydrochloride Material Safety data sheet, 2010. anestetik N01BB52, 2010.

19. Moshaver A., Lin D.,The Hemostatic and Hemodynamic Effects of Epinephrine During Endoscopic Sinus Surgery, A Randomized Clinical Trial, 2010; 135(10): 1005-1009.

20. Van der Bijl P., Victor M., Adverse reaction associated with norepinephrine in dental local anesthesia, Anesth Prog, 1992; 39(3): 87-89.

21. Hirota Y., Hori T., Efects of epinephrine and norepinephrine contained in $2 \%$ lidocaine on hemodynamics of the carotid and cerebral circulation in older and younger adults, Anesth Pain Control Dent 1992; 40(6): 476-479.

22. Forth W., Henschler D., Rummel W., Allgemeine und speziale Pharmakologie und Toxikologie, Wiessenschaftsverlag, Bibliographisches Institut, Mannheim/Wien/Zrich, 1987. (German).

\title{
TERMOVIZIJSKO ISPITIVANJE VAZOKONSTRIKCIJE I VAZODILATACIJE KRVNIH SUDOVA POD UTICAJEM LOKALNIH ANESTETIČKIH RASTVORA
}

\author{
ĐUKIĆ Igor, SELAKOVIĆ Srećko, BUBALO Marija, SELAKOVIĆ Jovana, \\ TATIĆ Zoran
}

Kvalitetna lokalna anestezija je jedan od imperativa izvođenja stomatoloških intervencija, a naročito oralnohirurških intervencija, gde se kroz uspešnost lokalne anestezije ogleda i uspešnost oralnohirurške intervencije. Na tržištu se nalazi veliki broj različitih lokalnih anestetičkih rastvora (LAR) sa različitim koncentracijama vazokonstriktora kojima se pripisuje da izazivaju brojne komplikacije prilikom davanja lokalne anestezije. Cilj istraživanja je da se ukaže na temperaturne promene koje izazivaju različiti LAR, u zavisnosti od jačine i koncentracije LAR primenom termovizijske kamere. Ispitivanje je rađeno na 70 eksperimentalnih Wistar pacova, uzrasta 4,5 meseca, prosečne težine 250 grama, muškog pola, podeljenih u sedam grupa od po 10 životinja u zavisnosti od anestetika koji im je aplikovan. Nakon ubrizgavanja anestetičkog rastvora u butnu regiju uključuje se štoperica i vrše se kontrolna merenja u periodu od dva časa. Svi snimci su sa termokamere naknadno transferovani na kompjutersku jedinicu. Pojava više temperatura u ispitivanoj regiji pacova u odnosu na kontrolnu regiju uočena je samo kod aplikacije 2\% čistog lidokaina (bez vazokonstriktora). Najveći pad temperature u odnosu na kontrolnu regiju pet minuta nakon aplikacije lokalnog anestetika primećen je kod 2\% mepivakaina sa adrenalinom (1: 100 000) i 2\% mepivakaina sa noradrenalinom $(1: 100$ 000). Vazokonstriktorni efekat najizraženiji je u petoj minuti 
po aplikaciji LAR i postoje minimalne razlike između efekata adrenalina i noradreanlina u ispitivanim kombinacijama sa LAR. 